\title{
President Trump's Declarations on Official Development Assistance: A Change of Policy?
}

\author{
Michał Zaremba \\ University of Łódź \\ Faculty of Economics and Sociology \\ Institute of Economics \\ Department of Development Economics \\ e-mail: michal.zaremba@uni.lodz.pl
}

\begin{abstract}
For years official development assistance (ODA) has been one of the most important forms of financial assistance provided to developing countries by highly developed countries. Despite the controversy over the effectiveness of assistance, it has become a permanent element of the international aid system. With the election of Donald Trump and one of the key slogans of his campaign - America first - the political climate around official development assistance is changing. The aim of the article is to analyze the role of official development assistance in political declarations of the current president of the United States.
\end{abstract}

Keywords: official development assistance, USA, Donald Trump, international political economy. 


\section{Introduction}

During its existence, the official development assistance (ODA) system has become one of the most important tools for supporting developing countries in overcoming development problems and helping them to enter a sustainable and balanced path of growth and socio-economic development. Traditionally, the role of donors was restricted to the so-called rich North, which meant Western European countries, the USA and Canada, as those countries largely shaped and implemented development policy that supported poor developing countries.

With the election of Donald Trump and one of the key slogans of his campaign - America first - the political climate around official development assistance is changing. The aim of the article is to analyze the role and importance of official development assistance in political declarations of the current president of the United States. The article presents briefly the characteristics of official development assistance and then the characteristics of selected announcements of changes in the US foreign economic policy. In the last part a critical analyses of Trump's statements regarding official development assistance will be conducted.

\section{International development assistance system}

One of the most important problems of the modern world is the problem of global imbalances in the level of socio-economic development of individual regions, which potentially represents a significant prerequisite for the emerging of new conflicts. For this reason, development assistance plays an important role in the world and has been a subject of profound research in the social sciences.

Reasoning for development assistance was justified in the development models created after World War II. According to the theory, each monetary unit of an exogenous character increases the beneficiary savings resources that could be spent on investment. The best known is model proposed by Roy F. Harrod and Evsey D. Domar, who relied on these assumptions. Hollis B. Chenery and Allan M. Strout, basing on their model, created so called two-gap model, which justifies the role of development assistance as a stimulus for economic development. This model, despite the criticism, is still treated as a justification for the development assistance and the global assistance system (Easterly, Can Foreign Aid Buy Growth?, 32-33).

Development assistance can also be seen as a political instrument in the post-colonial system, allowing or sustaining strategic control on the developing countries, which was particularly evident during the Cold War (Véron, 7). This problem is still important, as many studies consistently show that the non-formal determinants, like former colonial ties, the method of voting in the UN or the historical and geostrategic considerations, are often the main determinant of assistance (Easterly, 
Are Aid Agencies Improving, 646-651; Noorbakhsh, Paloni, 928; Mawdsley, 502-503; Hansen, Tarp, 375-398).

Researchers distinguish two groups of factors determining aid: non-political and political (Round, Odedokun, 302-303). The first group includes:

- level of income per capita;

- business cycle phase;

- the level of budgetary expenditure and the budget deficit;

- peer pressure (the herd effect) - the amount of development assistance depends on the amount of assistance granted by other donors;

- level of social protection in domestic politics - the lower it is, the less altruism is expected;

- size of the state, geopolitics and geoeconomics associated with the country;

- other temporary factors.

Political determinants include:

- the ideological orientation of the donor;

- the constitutional independence of decision-makers;

- the balance of power in the government, determining the situation in the country.

Since 2005, the total amount of assistance was more than $\$ 100$ billion per year, what more the "traditional" donor countries (the so-called Rich North) have been followed by Arab donors (Saudi Arabia, Kuwait, the United Arab Emirates) and the countries referred to as the "new" donors: China, Brazil, India, South Africa and Russia. Each group of donors has its own rules, but the most formal form of assistance has been developed by OECD countries within the official development assistance framework.

The official development assistance (ODA) is understood as donations and loans provided to developing countries by official government institutions of donor countries or international organizations supporting economic development and prosperity in these countries. Loans are counted as official development assistance only if they include a donation of at least $25 \%$ of the value of the assistance. List of assistant recipient countries is periodically revised in accordance to the classification of the Development Assistance Committee (DAC) of the OECD (DAC Statistical..., 11; Deszczyński, 79, 84-87; Bagiński, Kowalska, 89-92). In order to classify resources as ODA, following conditions must be fulfilled:

- they are provided by the official sector of the state (government or local authorities);

- the aim of transferred funds is socio-economic development;

- they have a preferential character, which is manifested among other in donation component;

- the transfer recipient (beneficiary country) is listed on the DAC List of ODA Recipients. 
Overall development assistance to developing countries increased over time, becoming an important component of international politics countries known as Global North (Table 1).

Table 1. Value of ODA for certain highly developed countries in 2017

\begin{tabular}{|c|c|c|}
\hline Country & $\begin{array}{l}\text { Value of assistance } \\
\text { (billions of USD) }\end{array}$ & Share of total assistance (\%) \\
\hline Australia & 3025 & 2,12 \\
\hline Austria & 1583 & 1,11 \\
\hline Belgium & 2306 & 1,62 \\
\hline Canada & 3962 & 2,78 \\
\hline Czech Republic & 261 & 0,18 \\
\hline Denmark & 2372 & 1,66 \\
\hline Finland & 1057 & 0,74 \\
\hline France & 9501 & 6,66 \\
\hline Germany & 24670 & 17,30 \\
\hline Greece & 264 & 0,19 \\
\hline Hungary & 155 & 0,11 \\
\hline Iceland & 50 & 0,04 \\
\hline Ireland & 802 & 0,56 \\
\hline Italy & 4856 & 3,40 \\
\hline Japan & 10368 & 7,27 \\
\hline Luxemburg & 384 & 0,27 \\
\hline The Netherlands & 4988 & 3,50 \\
\hline New Zealand & 438 & 0,31 \\
\hline Norway & 4352 & 3,05 \\
\hline Poland & 603 & 0,42 \\
\hline Portugal & 340 & 0,24 \\
\hline Republic of Korea & 1965 & 1,38 \\
\hline Slovakia & 107 & 0,08 \\
\hline Slovenia & 80 & 0,06 \\
\hline Spain & 4096 & 2,87 \\
\hline Sweden & 4870 & 3,41 \\
\hline Switzerland & 3563 & 2,50 \\
\hline The United Kingdom & 18013 & 12,63 \\
\hline The USA & 33589 & 23,55 \\
\hline Total & 142619 & 100 \\
\hline
\end{tabular}

Source: Based on International Development Statistics (IDS) online databases http://www.oecd.org/ dac/stats/data.htm 
Objectives of the assistance changed during the time in accordance to the doctrine of economic development and political situation in the world. Depending on the recommendations, the countries spend assistance on poverty reduction, sustainable development or increasing the commercial potential recipient. Later, the list of objectives was enriched with promoting gender equality, empowerment of women, conflict prevention, and more recently, improving the quality of governance. In addition, the DAC recommends non-repayable assistance as the basis for the functioning of development aid (Nowak, 46o).

\section{Changes in US foreign economic policy - the era of Trumponomics?}

The candidate Trump and the President-elect Trump, aroused both interest and controversy from the very beginning, becoming the subject of broad analyzes. One of the most important research areas is the issue of economic policy conducted by the new president.

The declarations and the steps already taken in the field of economic policy are collectively referred to as Trumponomics, evoking a clear association with Ronald Reagan's Reaganomics. Undoubtedly, the most important axis around which economic policy is being built is the slogan America first, which at least declaratively means a desire to revise the current model of world trade and globalization. Concrete actions, if they are taken, may mean above all the renegotiation of trade agreements and the use of tariff instruments in trade policy, and hence the return, at least to some extent, of protectionist and mercantilist practices. Obviously, this would affect mainly Asian countries (primarily China), which financially and commercially want to dominate the USA. However, it is not certain how, in which form and when this policy could be applied. It should be borne in mind that Trump's foreign economic policy will reflect his own attiutudes in national politics. The existing declarations and actions indicate that the focus is on reducing tax burdens, primarily for enterprises, reducing administrative and legal requirements and simplifying them, as well as government infrastructure investments. The question to what extent the policy will actually be implemented remains a matter of debate, even though it was an important element of the election campaign and Trump's declarations.

Trump is not against free trade as such, but opposes multilateral trade agreements. Both the Trans-Pacific Partnership (TPP) and the Transatlantic Trade and Investment Partnership (TTIP) would not have any chance of success in the proposed form. It is worth noting that both Trump and Clinton opposed the TPP evoking negative impact on the US labor market. As Patten noted: “The case for tearing up free-trade agreements and aborting negotiations for new ones is premised 
on the belief that globalization is the reason for rising income inequality, which has left the American working class economically marooned" (Patten). By withdrawing from multilateral trade treaties or changing them, Trump strives to protect jobs in the American industry, and more generally: to stop negative trends as a result of changes in global order. Politically speaking, the rejection of a free trade agreement makes sense in domestic policy for at least two reasons. First, it would help Trump politically destroy the legacy of Obama's administration in terms of free trade, and secondly and more importantly: Trump can strengthen his political power, appealing to, at least, some of Bernie Sanders' supporters who as a candidate also raised issues related to the American labor market.

The problem is that Trump's free trade paradigm is ideologically closer to the mercantilist understanding of international trade than to the realities of a globalized world. In fact, Trump categorically expresses its opposition to globalization in its current form: "No country has ever prospered that failed to put its own interests first. Both our friends and our enemies put their countries above ours and we, while being fair to them, must start doing the same. We will no longer surrender this country or its people to the false song of globalism. The nationstate remains the true foundation for happiness and harmony. I am skeptical of international unions that tie us up and bring America down and will never enter" (Trump). Trump has repeatedly stated that the US political elite consistently implements the globalization policy that has enabled the transfer of jobs, capital and technology to other countries. Trump's opposition to globalization is emphasized by his view that international institutions such as the World Trade Organization, NATO or the UN that set, in his view, unacceptable restrictions on the American policy (Shuster 2016).

Trump is not only skeptical about globalization (at least in its present form), but at the same time is particularly focused on the thesis that political and economic power of the state has been weakened by non-state forces, such as large international corporations that are transferring their activities to developing countries, which results in an increase in unemployment in developed economies. Societies in developed countries have negative views on economic, political and cultural globalization, which corresponds with Trump's populist rhetoric known under political slogan Make America Great Again.

In summary, in the case of Trump, we have revolutionary announcements, largely questioning the current political and economic consensus. Trump as a realistic, not idealistic neo-mercantilist captured the real dissatisfaction of the electorate sense of wrong and injustice. Nevertheless, the final, real decisions must pass the entire parliamentary procedure. But the Congress likewise the whole country, is very divided. In addition, the fact that Trump has no political experience means that the situation is uncertain and we might experience many odd decisions regarding foreign and domestic policies. 


\section{Official development assistance in political statements of Donald Trump}

It is worth noting that the US is in absolute terms the largest donor of foreign aid in the world (Figure 1). Trump's views on trade and globalization give insight into how his administration may understand the role of foreign assistance.

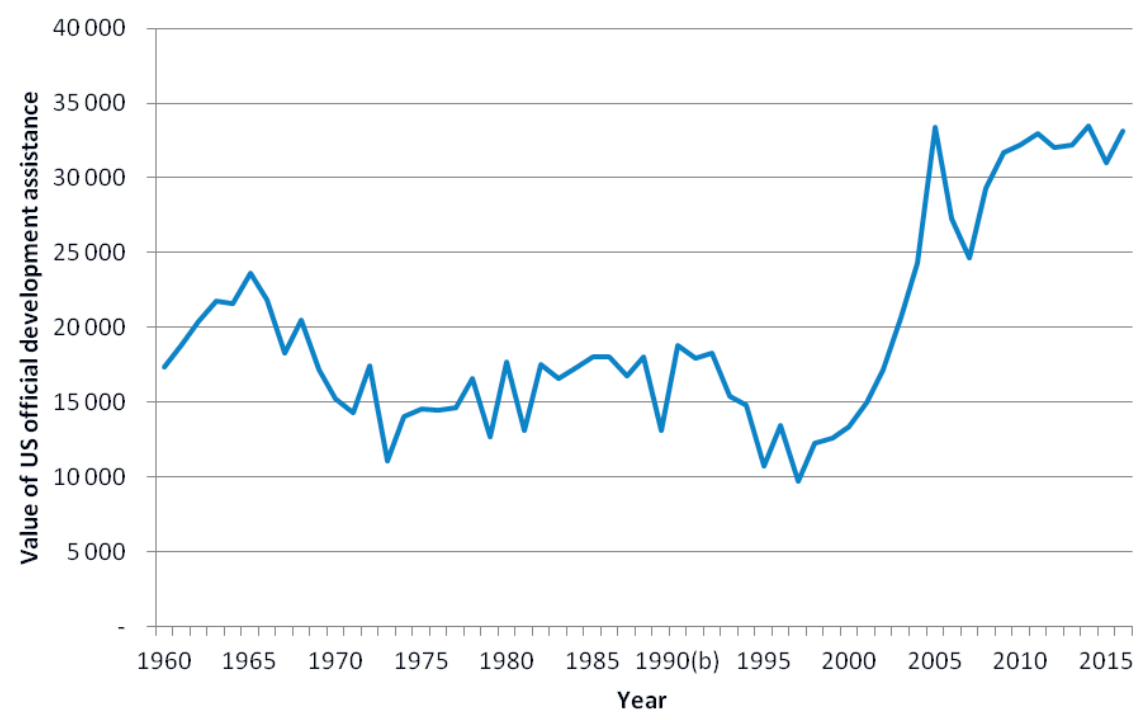

Fig. 1. Value of US official development assistance in 1960-2015 in fixed prices from 2015 Source: Based on: International Development Statistics (IDS) online databases http://www.oecd.org/ dac/stats/data.htm

In Trump's thinking, foreign assistance is not a "different kind", but a complementary element of foreign trade policy, part of the overall economic program. Trump formulated a foreign aid program according to a new, protectionist key, stating: "The most important difference between our plan and our opponent is that our plan will put America first. Americanism, not globalism, will become our credo... the Americans will be the first again". (Smith). In addition, he declared that: "It is necessary to invest in our infrastructure and stop sending foreign aid to countries that hate us and use this money to rebuild our tunnels, roads, bridges and schools" (Tyson).

If such announcements were to come true, this could mean the end of the United States Agency for International Development (USAID) and development policies that currently exist. The heart of the matter is that Trump treats spending money to help developing countries legitimate if it is to provide the US with commercial or security-related benefits. In other words, the current development assistance 
provided by the USA in the form of official development assistance did not make the US safer or richer. More specifically, Trump expressed his opposition to development aid because it does not succeed and does not meet the expectations of the USA.

Perhaps the most likely change in Trump's administration will be the increase in the conditions for receiving development funds and linking them with international trade. It would mean significant and fundamental changes in foreign assistance policy. This seems to reflect the appeal of Republicans who opt for reducing the funding of the Department of State, diplomacy and foreign assistance and reducing involvement in humanitarian operations around the world (McKnight Nichols). It is not clear to what extent the development assistance based on Trumponomics will aim at a real fight against poverty. It is possible that ultimately reducing poverty in developing countries receiving assistance directly or indirectly from the US will be a side effect rather than a planned goal.

Under the America First concept, drastic cuts are planned regarding programs for developing countries, as well as integrating USAID with the Department of State. Funds for these purposes in 2018 would be reduced by over 1/3. In addition, the budget documents assume redirecting funding from development assistance to programs closely related to the goals of national security. In the justification of his decision, the Trump administration writes about providing more effective actions through reorganization and consolidation to enable effective diplomacy and development. Suggested proposals are aimed at a reconstruction of the federal budget and they would be the subject of long-term consultations and arrangements between the administration and both chambers of Congress (Harris, Gramer, Tamkin).

In conclusion, it should be stated that in Donald Trump's announcements, the question of development aid for developing countries is primarily considered in the context of foreign policy as such. Trump's skepticism towards the present world order and more or less open criticism of the adopted model of globalization and world trade clearly affects the problem of development assistance. The assistance will most likely go to countries that can help the US protect itself against terrorism and those countries that provide commercial benefits to the US economy. It is obvious that not all aid for poor countries can be considered "good" for the United States and their development.

\section{Conclusions}

Development assistance is one of the most important forms of assistance to developing countries. Traditionally, the role of donors was restricted to the rich countries of the West, especially former colonizers and the USA, as the most important country in contemporary political and economic relations. 
The election of Donald Trump for the presidential office and his declarations promise major changes in the current model of broadly defined foreign policy - also in the area of development assistance for developing countries. Taking into account the declarations and announcements of the current president, major changes and revisions to the current aid model can be expected. Trump referred them as an ineffective instrument that does not live up to expectations. According to the president's logic, the US must redirect these funds to national projects. The future of the assistance is therefore uncertain.

In any case, US changes in official assistance policy will have a significant impact on the functioning of global development assistance. According to the announcements of the current president, one can expect a greater pragmatism, skepticism and distrust regarding assistance policy. Considering the overall policy, one can certainly expect significant changes, which, as a last resort, may completely change the nature of development aid.

\section{Works Cited}

Bagiński, P., and Kowalska M. Finansowanie rozwoju krajów słabiej rozwiniętych jako element polityki zagranicznej państw rozwiniętych, [in:] Pomoc rozwojowa dla krajów rozwijających się na przełomie XX i XXI wieku, ed. E. Latoszek. Warszawa: Wydawnictwo SGH, 2010.

DAC Statistical Reporting Directives, DCD/DAC(2010)40/REV1, Development Cooperation Directorate, Development Assistance Committee. Paris: OECD, 2010.

Deszczyński, P. Konceptualne podstawy pomocy rozwojowej. Poznań: Wydawnictwo UE, 2011.

Easterly, W. Are Aid Agencies Improving. "Economic Policy", vol. 22, no. 52 (2007), pp. 633-678.

Easterly W. Can Foreign Aid Buy Growth? "Journal of Economic Perspectives", vol. 17, no. 3 (2003), pp. 23-48.

Hansen, H., and Finn, T. Aid Effectiveness Disputed. "Journal of International Development", vol. 12, Issue 3 (2000), pp. 375-398.

Harris, Byant, Gramer, Robbie, Tamkin, Emily. The End of Foreign Aid As We Know It. Trump budget would gut development assistance and fold USAID into State. "Foreign Policy" (April, 2017). Web. 15 November 2018, http://foreignpolicy. com/2017/04/24/u-s-agency-for-international-development-foreign-aid-statedepartment-trump-slash-foreign-funding/.

International Development Statistics. OECD online databases. Web. 21 December 2017, http://www.oecd.org/dac/stats/data.htm.

Mawdsley, E. The Millennium Challenge Account: Neo-liberalism, Poverty and Security. "Review of International Political Economy", vol. 14, no. 3 (2007), pp. 487-509. 
McKnight N.Ch. Trump's Misguided and Empty Promise of Protectionism Dovetails with His Appeal to Isolationism. "History News Network" (April, 2016). Web. 15 November 2018, http://historynewsnetwork.org/article/162423.

Noorbakhsh, F., Paloni A. Learning from Structural Adjustment: Why Selectivity May Not Be the Key to Successful Programs in Africa. "Journal of International Development”, vol. 19, Issue 7 (2007), pp. 927-948.

Nowak, W. The Evolution of Development Assistance. "Journal of US-China Public Administration”, vol. 11, no. 5 (2014), pp. 454-462.

Oreskes, B. UN braces for Trump-style diplomacy. "Politico" (January, 2016). Web. 15 November 2018, http://www.politico.com/story/2016/11/united-nations-donald -trump-effect-231626.

Patten, C. Will Trump Bring Down the West? "The Project Syndicate" (November, 2016). Web. 15 November 2018, https://www.project-syndicate.org/commentary/ trump-threat-to-the-west-by-chris-patten-2016-11.

Round, J.I., Odedokun, M. Aid Effort and Its Determinants. "International Review of Economics and Finance", vol. 13, Issue 3 (2004), pp. 293-309.

Shuster, S. Can NATO Survive a Donald Trump Presidency? "Time” (November, 2016). Web. 15 November 2018, http://time.com/4569578/donald-trump-nato-alliance -europe-afghanistan/.

Smith, D. Trump's Republican convention speech: what he said and what he meant. “The Guardian" (June, 2016). Web. 15 November 2018, https://www.theguardian. com/us-news/ng-interactive/2016/jul/22/donald-trump-republican-convention -speech-transcript-annotated.

Trump, D. Donald Trump's Foreign Policy Speech. “The Federal News Service” (April, 2016). Web. 15 November 2018, http://www.nytimes.com/2016/04/28/us/politics/ transcript-trump-foreign-policy.html?_r=0.

Tyson, J. Trump on foreign aid. "Devex" (September, 2016). Web. 15 November 2018, https://www.devex.com/news/trump-on-foreign-aid-86916.

Véron, J-B. L’Aide au développement. Evolutions récentes et grands débats. Paris: Agence Français de Développement, 2005.

Michał Zaremba, MA - assistant at the Department of Development Economics of the University of Lodz. Research interests focus on the development problems of Asian countries, with a special focus on India and China. In his doctoral dissertation, he examines the role of market mechanisms and state tools in India's economic development since its independence in 1947. Author of many articles and participant of numerous conferences. Member of Polish Economic Association and Polish Association for International Studies. 